\title{
Analysis of the thermal sensation in cold period outdoor spaces, in the dry climate of the metropolitan area of Tijuana, Baja California, Mexico
}

\section{Análisis de la sensación térmica en espacios exteriores periodo frío, en el clima seco de la zona metropolitana de Tijuana, Baja California, México}

SAHAGUN-VALENZUELA, Miguel Isaac*†, ZARATE-LOPEZ, María de los Ángeles, PITONESRUBIO, Juan Antonio and ALMEJO-ORNELAS, Alberto

Universidad Autónoma de Baja California

ID $1^{\text {st }}$ Author: Miguel Isaac, Sahagun-Valenzuela / ORC ID: 0000-0001-6363-0884, CVU CONACYT ID: 397669

ID $1{ }^{\text {st }}$ Co-author: María de los Ángeles, Zarate-Lopez / ORC ID: 0000-0002-1554-5439, CVU CONACYT ID: 208478

ID $2^{\text {nd }}$ Co-author: Juan Antonio, Pitones-Rubio / ORC ID: 0000-0002-9897-1846, CVU CONACYT ID: 40718

ID $3^{\text {rd }}$ Co-author: Alberto, Almejo-Ornelas / ORC ID: 0000-0002-0461-93-83, CVU CONACYT ID: 239125

DOI: $10.35429 / J U S D .2021 .20 .7 .17 .23$

Received: March 10, 2021; Accepted June 30, 2021

\begin{abstract}
Weather variables affect the permanence of a user at an outdoor public space, the diverse aspects of these variables can affect the user's thermal sensation. Thus, by knowing the outdoor comfort temperatures or neutrality temperatures values, users can extend their stay in the areas that are exposed to outdoor weather conditions, a reason why we intend to find the values for those neutral temperatures on the outdoor spaces at the Valle de las Palmas area, in Tijuana, Baja California, because by knowing these values, there can be improved outdoor spaces designed in accordance to the city's climate variables. In order to find these temperature values, a case study was selected, in which an instrument or survey was applied, designed to inquire what the perceived thermal sensation of the user at the open space is, while thermal monitoring was carried out at the same time with the use of automated measurement tools and, once the data was gathered, diverse variables were collected based on the ISO 7730-2005 standard, while Microsoft Excel software was used to analyze the field data and, as a result, the appropriate neutrality temperature was obtained to be able to design future outdoor spaces or redesign and improve the existing ones.
\end{abstract}

Thermal Sensation, Neutral Temperature, Outdoor Spaces

\section{Resumen}

Las variables climatológicas afectan la permanencia de un usuario en un espacio público exterior, los diversos aspectos de estas pueden alterar la sensación térmica del usuario, por lo que al saber cuáles son las temperaturas de confort exteriores o temperaturas de neutralidad el usuario puede alargar su estadía en las áreas expuestas a las condiciones exteriores, es por lo anterior que se busca conocer cuáles son esas temperaturas neutras en los espacios exteriores para la zona de Valle de las Palmas, Tijuana, Baja California, ya que al conocer cuáles son, se pueden diseñar espacios exteriores acordes al tipo de clima de la ciudad. Para conocer dichas temperaturas se seleccionó un caso de estudio, en el cual se aplicó un instrumento o encuesta, diseñado para conocer cuál es la sensación térmica percibida del usuario del espacio abierto, a la vez se realizó un monitoreo térmico con instrumentos de medición automática, y se recopilaron diversas variables basado en la norma ISO 7730-2005, una vez recopilados los datos se utilizó el software de Microsoft Excel para hacer el análisis de los datos de campo y, como resultado, se obtuvo la temperatura de neutralidad adecuada para poder diseñar futuros espacios exteriores o rediseñar y mejorar espacio ya existentes.

Sensación Térmica, Temperatura Neutra, Espacio Exterior

Citation: SAHAGUN-VALENZUELA, Miguel Isaac, ZARATE-LOPEZ, María de los Ángeles, PITONES-RUBIO, Juan Antonio and ALMEJO-ORNELAS, Alberto. Analysis of the thermal sensation in cold period outdoor spaces, in the dry climate of the metropolitan area of Tijuana, Baja California, Mexico. Journal of Urban and Sustainable Development. 2021. 7-20: $17-23$

*Correspondence to the author (e-mail: isaacmk17@gmail.com)

$\dagger$ Researcher contributing as first author 


\section{Introduction}

When using an outdoor space, the amount of time in which this space can be used depends on the existing level of comfort in said place. Since it depends on several aspects, including thermal comfort and, unlike indoor spaces where an artificial climate system such as air conditioning or heating ventilation can manage to control temperature to stay within the thermal comfort range, outdoor spaces lack this type of climate control, which however can be improved by means of an adequate architectural design of such spaces and the use of techniques that could improve the direct incidence of the meteorological variables, which would help to induce users to stay longer at the outdoor space. However, in order to achieve this, it is necessary to find out the temperature value of the appropriate neutrality for the place.

In order to search for the thermal comfort temperature at an outdoor public space in the semi-desert climate of Tijuana, a survey was applied on a case study which was chosen for its analysis, where the thermal sensation of the surveyed users was evaluated. The data was collected during the winter season of 2020, the instrument included variables such as: user satisfaction within the temperatura range of the place, the type of clothing the users wore at the time, what were their temperature preferences compared at that moment or how they felt that there was humidity in the environment. Meanwhile, at the same time the temperature and relative humidity readings were recorded by means of data loggers. The design of the instrument is based on ISO 7730-2005 standard, while the survey has a scale of values that goes from one to seven, which ranges from very cold to very hot.

When analyzing the results of the data collected from the applied survey and the data logger, it is possible to find that the neutrality temperature (Tn), or thermal comfort temperature, is the result of the rating given by the user according to the scale of seven that grades the outdoor open space, thus the data can be applied at cities with a weather condition similar to that of Tijuana. To improve coexistence within the designed spaces which take into account the appropriate temperature, to achieve definition of the (Tn), a total of 145 surveys were conducted during 2020's winter season.
To obtain the diagnosis of a space in which it is shown that an area is within the range of its comfort zones, as well as the intervention about design strategies for parks or other open spaces, it is necessary to use strategies of inductive methods along with field research and climatic variables, all of this necessary to improve the length of used time of the spaces by the users. (Guzmán, F., \& Ochoa, J., 2014)

\section{Thermal comfort}

Since the start of human evolution, mankind has tried to change the environment in order to feel comfortable in its living space. This can be noted on the oldest houses from various civilizations on Earth, which date from ancient times through the modern era were it can be observed that, according to the type of weather, man seeks to adapt spaces to the local climate to feel comfortable. Nowadays, feeling comfortable at home or at the working space is still one of the most important aspects to consider when designing an architectural space whether indoor or at outdoors.

Thermal comfort, which is defined by the ISO 7730 (2005) standard as "That state of mind in which satisfaction within the thermal environment is expressed". The former is a definition which is adequate for most people and therefore is accepted, yet it is a term that has its own difficulty since it is based on the individual's subjectivity as he expresses it. Figure 1 shows the complexity of the evaluation of thermal comfort, in which there are two groups of people in the same city and at the same area, but in very different situations, however both cases demonstrate that they can be within thermal comfort despite the difference of conditions. (Chávez, F.J., 2002)El
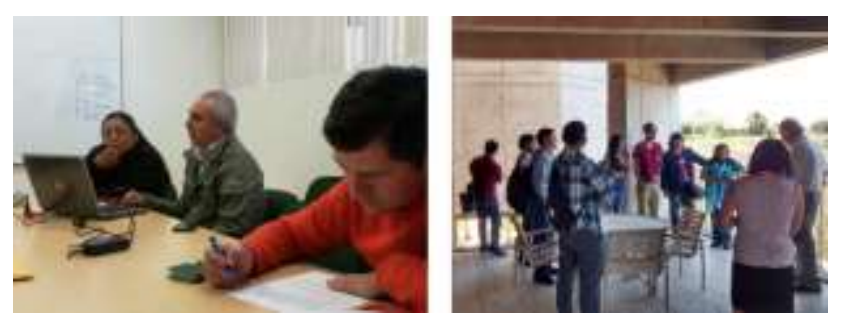

Figure 1 People in different conditions and enviroments, both cases in termal comfort Source: Author's archive 


\section{Methodology}

Study research of comfort in exterior spaces methodology has been developed recently, since there are different variables from those that affect thermal confort at indoor spaces. Thus, there is limited control of the aspects that affect outdoor spaces, that is why there is a greater complexity between the relationships of the studied parameters, being the reason that a greater variance occurs, due to the little control of the meteorological variables and the adaptation period for the user at the time of being outdoors (Gómez, et al., 2010).

Yanavilca, O., (2021), says in his research that, in order to estimate the thermal sensation of people in outdoor public spaces, relationships must be established among the measured values of the climatological data, and the sensation of thermal comfort of the users when using the analyzed space, thus, external factors such as air temperature or humidity must be considered, collecting data at different times of the day, which entails greater difficulty since the outdoor climatic conditions are variable and very different from those that occur within indoor spaces.

To collect the data, a survey was applied where the users subjectively express their thermal sensation at that moment. Weight and height data of the surveyed users were taken, as well as the dry bulb temperature and $\mathrm{RH}$ data. The surveys designed by Bojórquez, G., (2010), by Nikolopolou (2002) and by Guzmán, F., (2014) were taken as a basis for the development of the applied instrument.

The survey is divided into several sections, the first for space location data, the second for the type of activity that was carried out during the survey, the third for user data, the fourth section of the instrument is the most important since it is the one that collects the various aspects of the users' physical adaptation to the space, either due to their thermal sensation or humidity as well as their thermal preferences. In accordance with the ISO 77302005 classification, during the fifth section the weather data taken with the portable data loggers used were recorded after the event of the survey.
To make the selection of the measuring instruments for the survey, the reliability of use of the equipment, availability, ease of use to not require extensive training, were taken into account. The search resulted in the selected equipment with a reliability of $\pm 0.1^{\circ} \mathrm{C}$ and with a range of measurements that goes from $-20^{\circ} \mathrm{C}$ to $70^{\circ} \mathrm{C}$, and with a battery life of up to one year and more than fifty two thousand measurements (see figure 2).

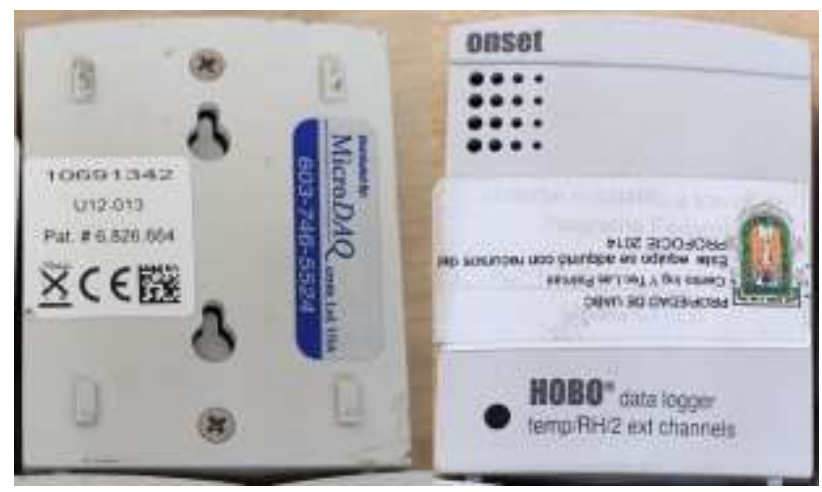

Figure 2 Measuring equipment used during research. Source: Author's archive

To carry out the analysis of the surveys, all responses were transferred into Excel spreadsheets, where the information collected from the surveys carried out on paper was captured. Once the database from the surveys and the data captured by the data loggers was created, the analysis of the forty three captured variables was continued, including the vote of the thermal sensation by users of the outdoor space.

\section{Location}

The survey application site was located within the Tijuana metropolitan area in the Valle de las Palmas academic unit which is located at coordinates $32^{\circ} 25^{\prime} 59^{\prime \prime} \mathrm{N}, 116^{\circ} 40^{\prime} 31^{\prime \prime} \mathrm{W}$ (see Figure 3). The Metropolitan Area of Tijuana includes the Municipalities of Tijuana, Tecate and Playas de Rosarito, the area is adjacent to the East with the Municipality of Mexicali, to the West with the Pacific Ocean, to the South with the Municipality of Ensenada and to the North with the San Diego County while to the Northeast is adjacent to Imperial County, both in the neighbouring state of California. 


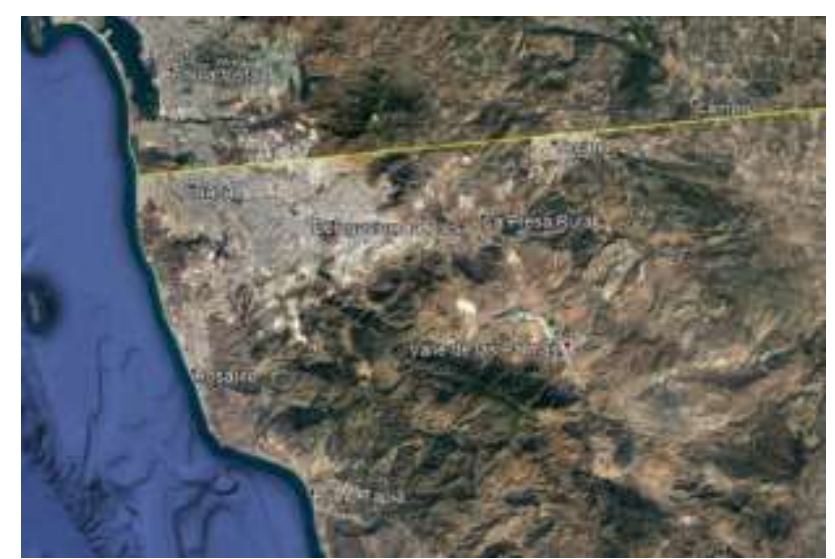

Figure 3. Map of Valle de las Palmas location Source: Google Earth application

The research is focused on the thermal comfort of the users of outdoor space, in which field information was collected during February 2020 through the survey developed for the study and with the use of the appropriate instruments to measure temperature and RH. All of the above conducted to evaluate thermal comfort in the analyzed outdoor public space.

The place selected to carry out the survey is located on the grounds of the Autonomous University of Baja California (UABC for short), which is located in Valle de las Palmas, Tijuana, Mexico. These are common public spaces, open to be visited by both the community from the UABC and by users who can reach the visiting campus (see Figure 4).

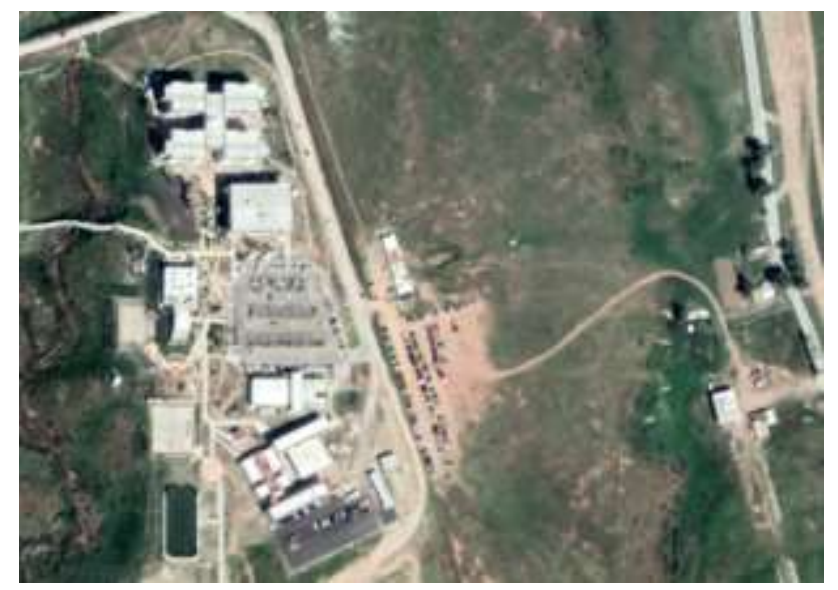

Figure 4. Aerial view of Valle de las Palmas campus Source: Google Earth

UABC's Valle de las Palmas campus is located within Tijuana's metropolitan area, to the southwest of the bordering area between the municipalities of Tijuana and Tecate. The Valle de las Palmas academic unit has an area of 240,668 $\mathrm{m}^{2}$ (about 59 acres).
It has large esplanades paved with concrete as well as some sports areas (see Figure 05).
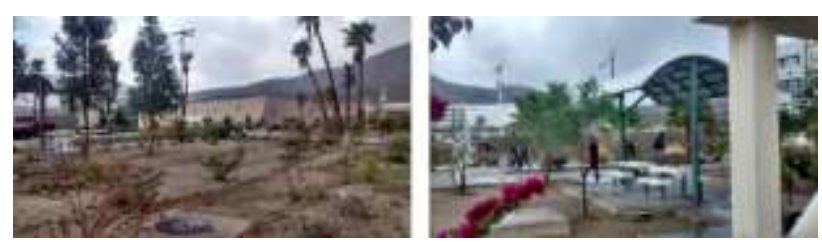

Figura 5 Common outdoor areas at Valle de las Palmas Source: Author's archive

\section{Data and results analysis}

While simultaneously monitoring meteorological variables along with the application of the user's subjective evaluation instrument, the maximum value of the ambient temperature or Temp. Amb. Max, registered a value of $17^{\circ} \mathrm{C}$. Likewise, a minimum value was registered for the ambient temperature or Temp. Amb. Min. which was $8^{\circ} \mathrm{C}$. Within the same record it was possible to obtain values for maximum relative humidity or R.H. Max, with a value of $26 \%$ and also the minimum value of relative humidity R.H. Min. which registered 20\% (see Table 1).

\begin{tabular}{|l|l|l|l|l|}
\hline \multicolumn{5}{|c|}{ Valle de las Palmas unit } \\
\begin{tabular}{|l|l|l} 
Temp. Amb. \\
Max ${ }^{\circ} \mathrm{C}$
\end{tabular} & $\begin{array}{l}\text { Temp. Amb. } \\
\text { Min }{ }^{\circ} \mathrm{C}\end{array}$ & $\begin{array}{l}\text { R.H. Max } \\
\%\end{array}$ & $\begin{array}{l}\text { R.H. Min } \\
\%\end{array}$ \\
\hline 17 & 8 & 26 & 20 \\
\hline Average: 12.5 & \multicolumn{3}{|l|}{ Average: 23} \\
\hline
\end{tabular}

Table 1 Variable maximum, minimum and average temperaturas recorded at Valle de las Palmas

Source: Author's archive

The data obtained in the field were analyzed and processed separately, grouping them according to ISO 7730 standard categories as can be seen in Table 2. For each of the groups, the mean temperatures were determined, as well as the standard derivation and, when any of the groups did not have enough reliable data, it was eliminated. By having the data analyzed, there were established ranges for each response, starting from the mean temperature or $T n$.

Finally, a linear regression was made with the resulting values, by which the straight lines corresponding to the extreme limits of the ranges were determined, defined by mean $\mathrm{Tn} \pm$ 2 , the close limits mean $\operatorname{Tn} \pm 1$, and those obtained with mean Tn. (Bojórquez, G., et al, 2010). 


\begin{tabular}{|l|l|}
\hline \multicolumn{2}{|c|}{ Thermal sensation } \\
\hline 7 & Very Hot \\
\hline 6 & Hot \\
\hline 5 & Somewhat Hot \\
\hline 4 & Neither Cold nor Hot \\
\hline 3 & Somewhat Cold \\
\hline 2 & Cold \\
\hline 1 & Very Cold \\
\hline
\end{tabular}

Table 2 Categories for vote of thermal sensation Source: ISO7730:2005

The survey was applied to a total of 145 people during the winter of 2020, each one giving their vote of perceived thermal sensation distributed as follows: $38 \%$ of the responses were for feeling an environment neither cold nor hot, which represents being neutral or comfortable, $36 \%$ gave their vote for feeling somewhat cold, which would be to have a slight discomfort to the perceived environment, and $29 \%$ of the votes were to be cold in the place, which represents feeling discomfort for the space regarding the thermal environment (see Figure 6).

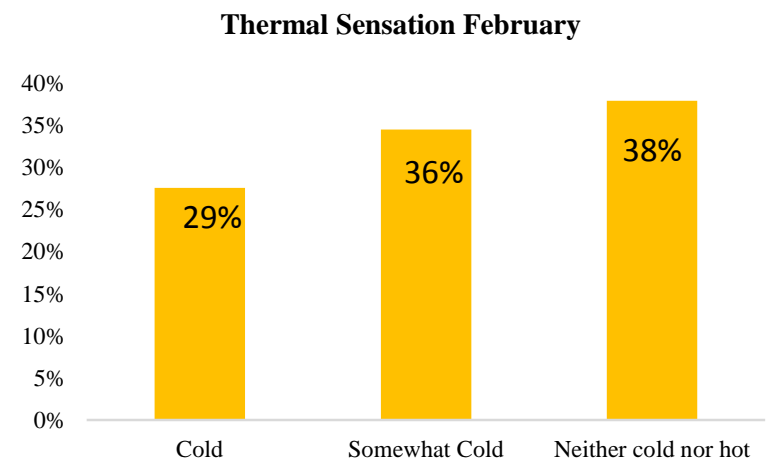

Figure 6 Percentages of the vote of thermal sensation Source: Author's archive

For data analysis, the Thermal Sensation Interval Measurement Method (MIST for short) was used, in which items were established to calculate the average values and the standard deviation of all the defined groups. With the method, a linear regression was performed, using only the mean values of the sample while not all the values were used, thus, each range is established by adding and subtracting the standard deviation of the sample once and twice (Bojórquez, G. , et al, 2010).

Once the MIST method was applied, the data that can be seen in Table 3 was obtained, where the Tn or Neutral Temperature can be appreciated, as well as the thermal comfort's reduced and extensive range values, based on the equation of the linear regression straight line applied for the mean values.

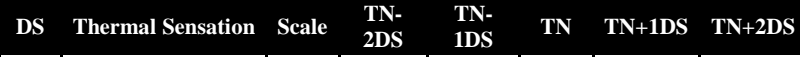 \begin{tabular}{|l|l|l|l|l|l|l|l|}
\hline 2.99 & Neither cold nor hot & 4 & 8.15 & 11.13 & 14.12 & 17.11 & 20.09 \\
\hline
\end{tabular}}

Table 3 Tn and narrow and long range Source: Author's archive

The neutrality temperature (or Tn) for the measured and analyzed space has a value of $14.12^{\circ} \mathrm{C}$, with a reduced range of thermal comfort of $5.98^{\circ} \mathrm{C}$, or $\pm 2.99^{\circ} \mathrm{C}$ from the neutrality temperature, and an extended range of thermal comfort of $11.96^{\circ} \mathrm{C}$, or $\pm 5.98^{\circ} \mathrm{C}$ from neutral temperature (see Figure 7).

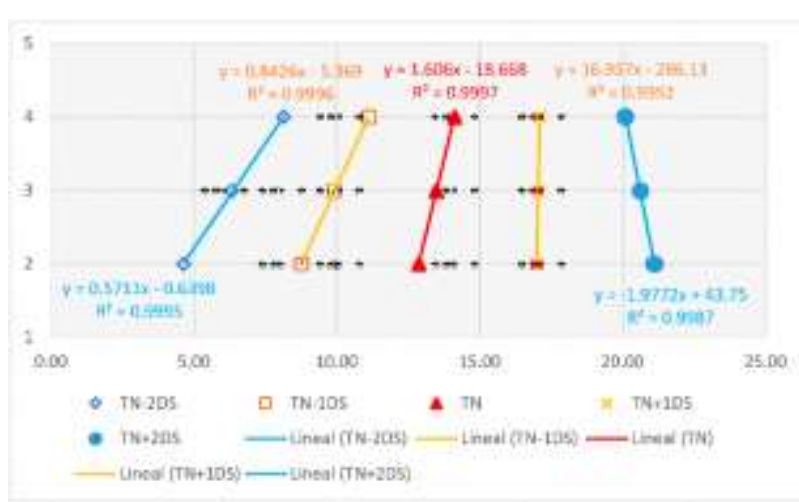

Figure 7 Thermal Sensation vote by ambience temperature

Source: Author's archive

It can be noted in Figure 7 how the users, despite being in the same place and within the same climate conditions, give a different vote of thermal sensation, which is because there are different aspects that can affect the vote of each individual. As the sociocultural physiological or psychological aspects at the moment, these aspects will be reflected in the emission of the vote given by the user during the survey. (Guzmán, F., \& Ochoa, J., 2014)

For the data of the results collected in the present investigation, it can be appreciated that $2.99^{\circ} \mathrm{C}$ resulted as the reduced range of thermal penalty for the analyzed space, and that the neutrality temperature of the space was established at $14.12^{\circ} \mathrm{C}$ (see Table 4).

\begin{tabular}{|r|r|r|r|r|r|r|r|}
\hline DS & Thermal Sensation & Scale & $\begin{array}{r}\text { TN- } \\
\text { 2DS }\end{array}$ & $\begin{array}{r}\text { TN- } \\
\text { 1DS }\end{array}$ & TN & TN+1DS & TN+2DS \\
\hline $\begin{array}{r}4.1 \\
1\end{array}$ & Cold & 2 & 4.65 & 8.76 & $\begin{array}{r}12.8 \\
8\end{array}$ & 16.99 & 21.10 \\
\hline 3.5 & Somewhat Cold & 3 & 6.33 & 9.90 & $\begin{array}{r}13.4 \\
8\end{array}$ & 17.06 & 20.63 \\
\hline 8 & Neither cold nor hot & 4 & 8.15 & $\begin{array}{r}11.1 \\
3\end{array}$ & $\begin{array}{r}14.1 \\
2\end{array}$ & 17.11 & 20.09 \\
\hline
\end{tabular}

Table 4 Neutrality temperature and standard deviation. Source: Author's archive 


\section{Conclusions}

During the instrument application used to assess the vote of the respondent's thermal sensation, weather presents an asymmetric behavior with a tendency towards cold temperatures, that is why no votes were given for warm sensations in the questionnaire, which shows a tendency towards adaptation to the cold period of the users.

If the comparison into account of $\mathrm{Tn}$, which was $14.12^{\circ} \mathrm{C}$, against the minimum ambient temperature recorded in the three ranges recorded, which was $8^{\circ} \mathrm{C}$, a difference of $-6.2^{\circ} \mathrm{C}$ can be appreciated and, since the reduced range had a value of $\pm 2.99^{\circ} \mathrm{C}$, it is concluded that this is the reason because the votes of thermal sensation tend to have a value of thermal discomfort. During the instrument application, there were $65 \%$ of the casted votes with some degree of discomfort.

Since the straight lines of the linear regression chart are not parallel, it means that the adaptation of the users to the space is not symmetrical as their perception of the temperature changes from hot to cold, since during cold periods sensations tend to be outside the thermal comfort range when using outdoor spaces.

When comparing variables resulting from the surveys applied to each user, along with the climate and vote made during the instrument application, the level of comfort in which the user was at the moment can be noted, resulting in a temperature of comfort, which can be used as a design temperature for planning future spaces which could have a climate similar to that of the case study of semidesert type.

As it can be appreciated in Table 4, the standard dispersions decrease as the average temperature of each of the ranges increases, which leads to the deduction that the lower the average temperature of the space after scale 4 (or neither cold nor hot), there is a greater consensus of discomfort due to thermal sensation in the place, as well as there is greater dispersion in the votes of thermal sensation due to the differences between the metabolism and activity of each surveyed individual.

\section{Acknowledgements}

To the students of research assistantships and scholarship holders, for their work in the field, in the capture and processing of data.

To the director and managers of FCITEC for their support during the investigation process.

To the Universidad Autónoma de Baja California for its financial support to carry out this research project.

\section{References}

Bojórquez G., Gómez-Azpeitia L., GarcíaCueto O., Ruiz-Torres R., Luna A., (2010). Temperatura neutral y rangos de confort térmico para exteriores, período cálido en clima cálido seco, Ambiente construido. Porto alegre, Volume 10, number 2, pages 133 to 143

Chávez, F.J. (2002). Zona variable de confort térmico. Doctoral Thesis, Universitat Politecnica de Catalunya.

Gómez N., Rojas A., Higueras E. (2010). Parámetros Sostenibles en el Planeamiento y Diseño Ambiental del Espacio Micro Urbano. Universidade do Algarve, Faro, Portugal

Givoni, B., Noguchi, M., Saaroni, H., Pochter, O., Yaacov, Y., Feller, N., Becher, S. (2003). Outdoor comfort research issues. Energy and buildings. Volume 35, Pages 77 to 86

Guzmán, F., \& Ochoa, J., (2014). Confort térmico en los espacios públicos urbanos clima cálido y frío semiseco, Hábitat sustentable. Volume 4, Number 2, pages 52 to 63

INTERNATIONAL ORGANIZATION FOR STANDARDIZATION. (2005). ISO 7730:2005 (E) Ergonomics of the thermal environment - analytical determination and interpretation of thermal comfort using calculation of the PMV and PPD indices and local thermal comfort criteria.

Nikolopoulou, M., (2004). Designing Open Spaces in the Urban Environment: A Bioclimatic Approach. Rediscovering the Urban Realm and Open Spaces, European Union: RUROS 
Linacre, E., \& Geerts, B. (1997). Climates and Weather Explained. London: Routledge

Ochoa, J., (2009). Ciudad, vegetación e impacto climático. El confort en los espacios urbanos. Barcelona: Erasmus Editions.

Olgyay, V., (2019). Arquitectura y Clima. Manual de Diseño Bioclimático para Arquitectos y Urbanistas. Barcelona: Gustavo Gili, Data Sheet

Yanavilca, O., (2021). Isla de calor urbano y su incidencia en el confort térmico de espacios públicos del sector El Progreso-Huanchaco 2018, Universidad Cesar Vallejo, Perú 